\title{
Humas Kantor Staf Presiden dalam Diseminasi Informasi Sosial dan Politik di Media Sosial
}

\author{
Lorensia, H.H. Daniel Tamburian \\ Danielt@fikom.untar.ac.id, danielt@fikom.untar.ac.id \\ Fakultas Ilmu Komunikasi Universitas Tarumanagara
}

\begin{abstract}
Social media almost used by the entire community. This social media is used to facilitate communication with each other. Therefore, the PR of the Presidential Staff Office also uses social media as a means to communicate, for example is to disseminate of social and political information to the public. The purpose of this study are to find out how the Public Relations of Presidential Staff Office using social media as a means to disseminate information quickly and effectively. This research is using descriptive qualitative study us with a case study strategy. The theories used in this study include communication, public relations, social media, and new media. Data collection for this study uses public relations interviews in Presidential Staff Office, literature studies and also by searching an online data.
\end{abstract}

Keyword: Social Media, Public Relation, Social and Political

\begin{abstract}
Abstrak
Media sosial merupakan media yang hampir digunakan oleh seluruh masyarakat. Media sosial ini digunakan untuk memudahkan komunikasi satu sama lain, maka dari itu Humas Kantor Staf Presiden (KSP) juga turut memanfaatkan media sosial ini sebagai sarana untuk berkomunikasi, salah satunya adalah menyebarluaskan informasi sosial dan politik kepada masyarakat. Maksud dari penelitian ini bertujuan untuk mengetahui bagaimana cara Humas KSP memanfaatkan media sosial sebagai sarana untuk menyebarkan informasi secara cepat dan efektif. Penelitian ini merupakan penelitian kualitatif dengan menggunakan metode studi kasus. Adapun teori yang digunakan di dalam penelitian ini, diantaranya seperti komunikasi, public relations, media sosial, dan new media. Pengumpulan data untuk penelitian ini menggunakan wawancara dengan Humas di KSP, studi pustaka dan juga dengan melakukan penelusuran data online.
\end{abstract}

Kata Kunci: Media Sosial, Public Relation, Sosial dan Politik

\section{Pendahuluan}

Indonesia merupakan negara kepulauan yang sangat luas dan memiliki jumlah penduduk yang sangat banyak, yaitu mencapai 265.015.030 jiwa (sumber: https://www.bps.go.id. Diakses pada tanggal 17 September pukul 14.22). Angka ini akan semakin meningkat setiap tahunnya dan tentu saja kita tak bisa menghindari adanya perubahan globalisasi. Peter Beger mengatakan bahwa globalisasi merupakan suatu kelanjutan dalam bentuk intensif yang di percepat dari tantangan yang sudah selalu ada terhadap modernisasi (Martin Wolf, 2004:21). Globalisasi yang kita kenal saat ini memiliki banyak perkembangan dan perubahan yang terjadi di sekitar kita, salah satunya adalah dengan kemajuan teknologi komunikasi dan informasi. Kemampuan teknologi komunikasi dan informasi dapat menjangkau ke seluruh tempat hingga pelosok-pelosok pedesaan. Dari sekian banyak kemajuan teknologi 
yang ada, yang paling cepat berkembang adalah teknologi yang menggunakan internet dan media sosial merupakan salah satu jaringan yang memanfaatkan teknologi internet tersebut.

Menurut Boyd (2009) mengatakan bahwa media sosial merupakan kumpulan perangkat lunak yang memungkinkan individu maupun komunitas untuk berkumpul, berbagi, berkomunikasi, dan dalam kasus tertentu saling berkolaborasi atau bermain. Media sosial memiliki kekuatan pada user-generated content (UGC) dimana konten dihasilkan oleh pengguna, bukan oleh editor sebagaimana di institusi media massa (Nasrullah, 2017:11). Media sosial merupakan jaringan teknologi yang paling digemari khalayak saat ini. Berdasarkan hasil riset dari KOMINFO tahun 2017, saat ini pengguna internet di Indonesia saat ini mencapai 63 juta orang dan 95 persen diantaranya menggunakan internet untuk mengakses jejaring sosial. Hal ini tentu mempengaruhi pelaksanaan tugas dan fungsi humas di lingkungan instansi pemerintah. Kini, banyak organisasi pemerintah yang turut menggunakan media sosial sebagai alat menyampaikan informasi (sumber: https://kominfo.go.id. Diakses pada tanggal 17 September pukul 15.12). Dinamika relasi antara humas dan media sosial menjelaskan bahwa beberapa studi menempatkan media sosial sebagai platform bagi public relations dalam menjalankan komunikasi publik.

Berdasarkan permasalahan tersebut, rumusan masalah dari penelitian ini adalah "Bagaimana Humas KSP Memanfaatkan Media Sosial untuk Menyebarluaskan Informasi Sosial dan Politik kepada Masyarakat?". Tujuan dari penelitian ini adalah untuk mengetahui bagaimana Humas KSP mengelola informasi sosial dan politik di media sosial.

Adapun beberapa teori yang digunakan, antara lain teori komunikasi, humas (public relation), humas pemerintah, media baru (new media), dan juga media sosial. Pemilihan teori-teori tersebut didasari oleh kesesuaiannya terhadap judul penelitian penulis. Teori utama yang penulis gunakan sebagai acuan adalah teori komunikasi menurut Menurut Everett $M$. Rogers yang mengatakan bahwa komunikasi merupakan suatu ide yang dialihkan dari sumber kepada satu penerima atau lebih, dengan maksud untuk mengubah tingkah laku mereka (Oktarina \& Abdullah, 2017:4) dan teori public relation menurut Hugo A. de Roode yang mengatakan bahwa pengertian public relation sebagai praktik dan juga seni dalam ilmu sosial untuk menganalisis kecenderungan mereka, menasehati para pemimpin organisasi, dan melaksanakan program yang direncanakan dari tindakan-tindakan yang akan melayani baik organisasi maupun interes publiknya (Liliweri, 2011:654).

\section{Metode Penelitian}

Dalam penelitian ini, penulis menggunakan metode kualitatif deskriptif. Metode penelitian kualitatif deskriptif ini dipilih penulis untuk dijelaskan secara rinci oleh humas pemerintah bagaimana mereka berperan aktif dalam menyebarluaskan informasi sosial dan politik kepada publik lewat media sosial, sehingga seluruh lapisan masyarakat dapat mengetahui informasi tersebut. Menurut Flick penelitian kualitatif adalah keterkaitan speisfik pada studi hubungan social yang berhubungan dengan fakta dari pluralisasi dunia kehidupan, yang diterapkan untuk melihat dan memahami subjek dan objek penelitian yang meliputi orang atau lembaga. Sementara itu, penelitian kualitatif menurut Bogdan \& Taylor (1990) adalah prosedur penelitian yang menghasilkan data deskriptif berupa kata-kata tertulis atau lisan dari orang- 
orang dan berperilaku yang dapat diamati dan diarahkan kepada latar individu secara utuh (Gunawan, 2014:82).

Metode pengumpulan data yang penulis lakukan adalah dengan melakukan wawancara dengan narasumber, melakukan observasi pada lokasi penelitian dan penelusuran melalui buku dan sumber online. Terdapat data primer dan data sekunder dalam penelitian ini. Data primer berupa berita-berita yang di unggah oleh Humas Kantor Staff Presiden di media sosial, sedangkan data sekunder berupa transkrip hasil wawancara oleh narasumber. Yang menjadi narasumber dalam penelitian ini adalah Bapak Agustinus Eko Rahardjo selaku Tenaga Ahli Madya, Kedeputian Bidang Komunikasi Politik dan Diseminasi Informasi, Kantor Staff Presiden.

Penulis melakukan analisis dari komunikasi yang berupa percakapan dan dituangkan dalam teks tertulis. Langkah pertama yang penulis lakukan adalah kemudian melakukan wawancara dengan narasumber dan melakukan observasi yang berkaitan dengan masalah penelitian. Lalu penulis mencari data-data melalui media sosial yang digunakan Humas KSP dan yang terakhir penulis menganalisis data-data yang diperoleh untuk mencari kesimpulannya.

\section{Hasil Temuan dan Diskusi}

Penulis melakukan wawancara dengan Humas Kantor Staff Presiden, karena Humas KSP memiliki kewajiban untuk melakukan fungsi pengendalian dalam rangka memastikan bahwa program-program prioritas nasional dilaksanakan sesuai visi dan misi Presiden. Selain melakukan pengendalian, Kantor Staf Presiden juga melaksanakan fungsi menyelesaikan masalah secara komprehensif terhadap program-program prioritas nasional yang dalam pelaksanaannya mengalami hambatan, termasuk dalam mengelola isu-isu strategis yang muncul dalam maskyarakat, agar isu-isu tersebut dapat dikelola terlebih dahulu supaya masyarakat dapat mengetahui kebenaran dari isu tersebut.

\section{Gambar 1. Foto bersama narasumber Bapak Agustinus Eko Rahardjo}

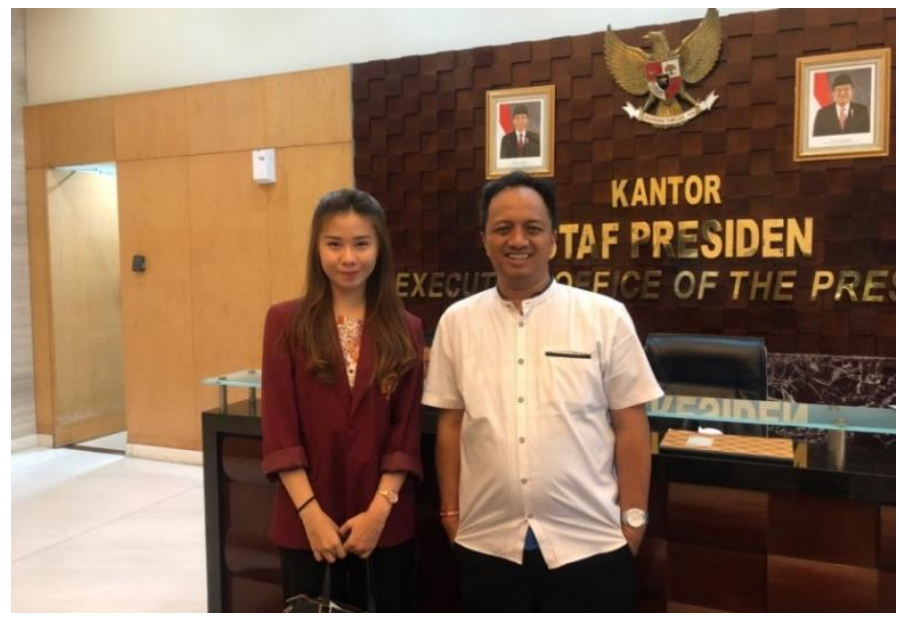

Sumber: Dokumentasi peneliti (2018)

Penulis melakukan wawancara dengan narasumber bernama Bapak Agustinus Eko Rahardjo atau yang biasa dikenal dengan Pak Jojo. Beliau merupakan Tenaga Ahli Madya, Kedeputian Bidang Komunikasi Politik dan Diseminasi Informasi, Kantor Staff Presiden. Wawancara dilakukan pada hari Senin, 22 Oktober 2018 pukul 15.00 - 
18.00 WIB. Beliau mengatakan bahwa Humas Kantor Staf Presiden bertugas untuk menyaring isu-isu yang muncul ketika suatu peristiwa terjadi, yaitu mengenai berita sosial dan politik. Ketika isu mengenai sosial dan politik muncul, Humas Kantor Staf Presiden akan langsung melakukan penyebaran informasi tersebut kepada publik melalui media sosialnya. Menurutnya, media komunikasi yang digunakan untuk menyampaikan pesan agar pesan tersebut cepat tersampaikan adalah melalui media sosial. Selanjutnya Humas Kantor Staff Presiden akan memberikan informasi tersebut kepada masyarakat melalui media sosial yang mereka miliki, agar pesan dapat tersampaikan dengan cepat ke seluruh masyarakat.

Media sosial utama yang digunakan oleh Humas Kantor Staff Presiden adalah website resminya yaitu www.ksp.go.id, namun ada juga beberapa media sosial lainnya yang digunakan seperti Instagram, Facebook, Youtube, dan Twitter. Dalam media sosial tersebut terdapat logo checklist bewarna biru yang menandakan bahwa media-media sosial ini merupakan media sosial resmi Kantor Staf Presiden yang digunakan oleh Humas Kantor Staf Presiden untuk menyebarkan informasi mengenai seputar informasi sosial dan politik. Narasumber juga mengatakan bahwa mediamedia sosial ini adalah media yang saat ini paling banyak digunakan terutama untuk masyarakat Indonesia.

Yang dilakukan Humas KSP adalah melakukan perencanaan pesan-pesan komunikasi yang akan disebarkan kepada masyarakat. Langkah pertama yang dilakukan adalah dengan selalu waspada dengan isu yang beredar atau selalu up to date dengan isu-isu yang bermunculan. Humas Kantor Staf Presiden akan memonitor isu-isu mengenai sosial dan politik, agar pesan dapat tersampaikan dengan cepat ke seluruh masyarakat. Selanjutnya, Humas Kantor Staf Presiden memberikan himbauan, menyaring isu yang beredar dan mengedukasi masyarakat untuk lebih paham mengenai seputar informasi sosial dan politik, terutama jika muncul isu berisi hoax tentang suatu berita, maka Humas Kantor Staf Presiden akan cepat melakukan verifikasi ke masyarakat bahwa isu tersebut tidak benar adanya. Jadi antara Humas Kantor Staf Presiden semaksimal mungkin memberikan keamanan dan kenyamanan kepada masyarakat Indonesia.

\section{Gambar 2. Berita yang di unggah di Instagram Kantor Staf Presiden}

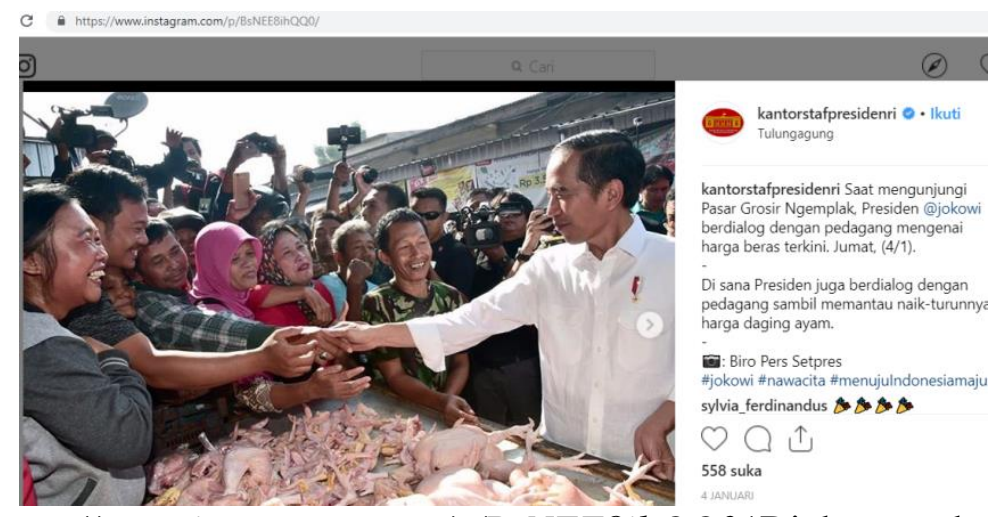

Sumber: https://www.instagram.com/p/BsNEE8ihQQ0/.Diakses pada tanggal 22 January 2019 pukul 13.03 
Lorensia, H.H. Daniel Tamburian: Humas Kantor Staf Presiden dalam Diseminasi Informasi Sosial dan Politik di Media Sosial

\section{Gambar 3. Berita yang di unggah di website Kantor Staf Presiden}

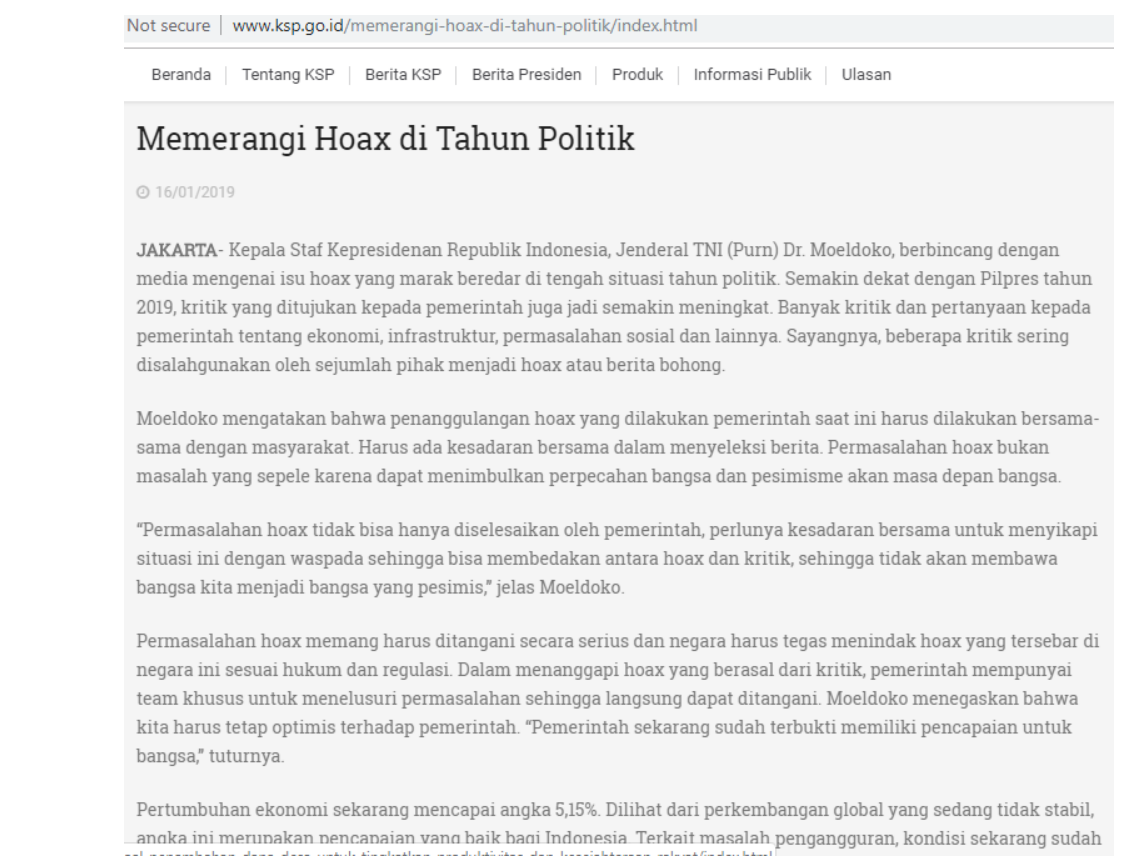

Sumber: http://www.ksp.go.id/memerangi-hoax-di-tahun-politik/index.html.

Diakses pada tanggal 22 January 2019 pukul 12.53

Berdasarkan anailisis isi, gambar diatas merupakan salah satu contoh konten berita sosial dan politik yang di unggah di website resmi Kantor Staf Presiden. Hal ini sejalan dengan fungsi komunikasi menurut Stanton dalam buku berjudul "Komunikasi Serba Ada Serba Makna" yang mengatakan fungsi komunikasi adalah untuk memberikan informasi agar masyarakat mengetahui hal tersebut, dan juga memberikan bantuan kepada masyarakat (Liliweri, 2011:128).

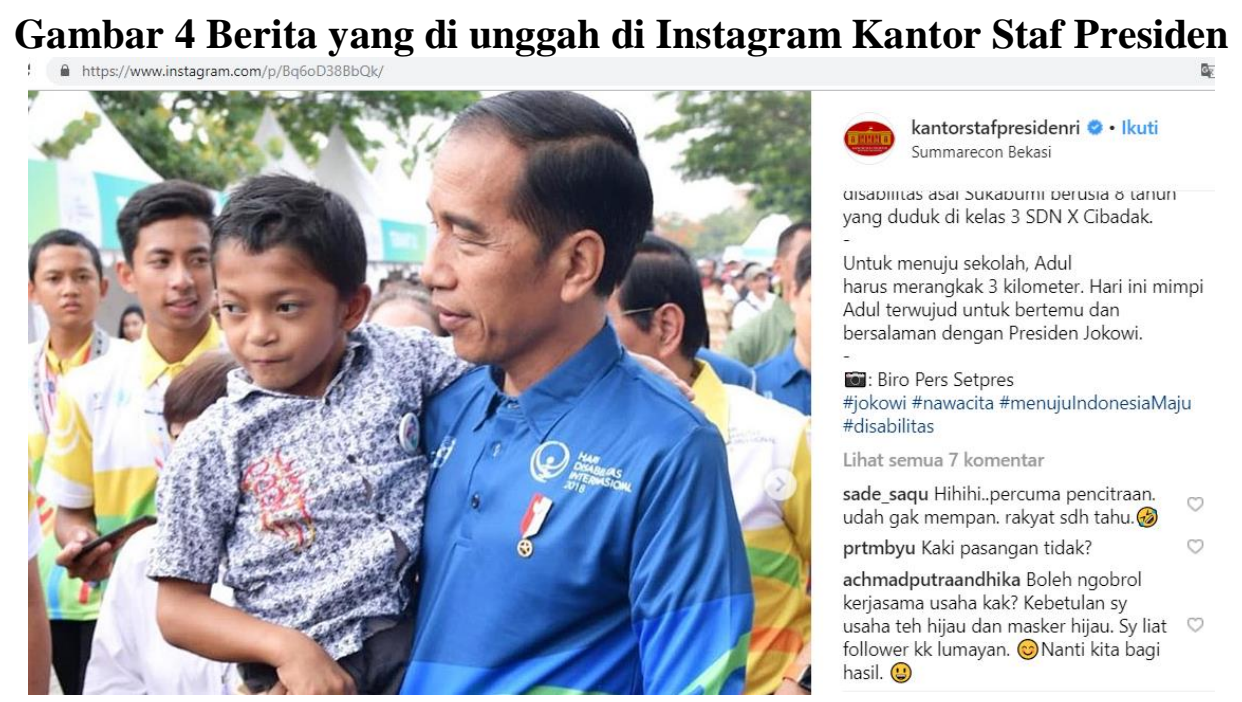

Sumber: https://www.instagram.com/p/BsNEE8ihQQ0/.Diakses pada tanggal 22 January 2019 pukul 13.10

Menurut analisa penulis menyimpulkan bahwa konten-konten diatas merupakan berita yang di informasikan kepada masyarakat yang telah di unggah, 
agar sebisa mungkin masyarakat mengetahui berita seputar sosial dan politik saat ini. Berita ini di unggah oleh Humas Kantor Staf Presiden. Hal ini juga sesuai dengan teori Hugo A. de Roode yang mengatakan bahwa public relation melaksanakan program yang direncanakan dari tindakan-tindakan yang akan melayani baik masyarakat maupun organisasi (Liliweri, 2011:654).

\section{Simpulan}

Setelah penulis melakukan penelitian terhadap pemanfaatan media sosial humas pemerintah dalam menyebarluaskan informasi sosial dan politik, maka penulis dapat menyimpulkan bahwa media sosial merupakan sarana komunikasi yang efektif dan tepat yang digunakan sebagai media komunikasi. Hal tersebut dapat dilihat dari salah satu fungsi media sosial yaitu dapat meberikan informasi yang cepat dan mudah diakses. Selain itu, media sosial digunakan oleh hampir seluruh lapisan masyarakat dan juga membantu Humas Kantor Staf Presiden dalam menyebarluaskan informasi sosial dan politik.

Humas KSP bertugas untuk menyaring isu-isu yang terkait dengan sosial dan politik dengan cara mencari kebenaran terkait isu yang beredar. Setelah itu jika memang isu yang beredar adalah benar, maka Humas Kantor Staf Presiden menyebarkannya melalui media sosial. Jika tidak, maka Humas Kantor Staf Presiden akan memberikan klarifikasi kepada masyarakat bahwa isu yang beredar tidak benar adanya dan menghimbau masyarakat agar tidak mudah percaya.

Media sosial yang digunakan, antara lain website resmi dari Kantor Staf Presiden yaitu www.ksp.go.id dan beberapa media sosial lainnya. Media sosial inilah yang dipakai untuk menyebarluaskan informasi terkait isu sosial dan politik.

Pak Jojo mengatakan besar harapannya kepada anak milenial saat ini untuk lebih aware dalam menggunakan media sosial, agar konten yang lebih edukatif dan informatif agar dapat berguna bagi masyarakat luas.

Saran yang ingin penulis sampaikan adalah semoga dapat dikembangkan dari kontennya agar terlihat lebih menarik sehingga khalayak lebih antusias dalam membaca informasi yang disajikan kepada seluruh lapisan masyarakat, kemudian lebih responsif terhadap isu-isu yang beredar di masyarakat dapat mengkonfirmasi isu-isu sosial dan politik yang tersebar agar masyarakat lebih aware.

\section{Ucapan Terima Kasih}

Penulis ingin mengucapkan terima kasih kepada:

- Ibu Dr. Riris Loisa, M.Si., selaku Dekan Fakultas Ilmu Komunikasi Universitas Tarumangara.

- Bapak Yugih Setyanto, S.Sos., M.Si., selaku Wakil Dekan Fakultas Ilu Komunikasi Universitas Tarumanagara.

- Ibu Sinta Paramita, S.I.P., MA., selaku Ketua Program Studi S.1 Ilmu Komunikasi Universitas Tarumanagara.

- Bapak H.H Daniel Tamburian S.Sos., M.Si., selaku pembimbing

- Bapak Agustinus Eko Rahardjo yang telah bersedia menjadi narasumber penulis.

- Orang tua dan teman-teman Fikom UNTAR yang telah menjadi teman seperjuangan dari awal masuk kuliah hingga saat ini 
- Seluruh staff dan karyawan UNTAR yang telah membantu penulis dalam memenuhi hal-hal yang diperlukan untuk melakukan penelitian.

Penulis menyadari bahwa penyusunan jurnal skripsi ini masih jauh dari kata sempurna, maka dari itu saran positif dan membangun sangat diperlukan agar penulis bisa lebih baik kedepannya. Akhir kata, penulis ingin memohon maaf jika ada kesalahan nama ataupun kata-kata lain yang ada di dalam penulisan jurnal skripsi ini. Terima kasih pada semua orang yang telah membantu selama penulisan laporan jurnal skripsi ini. Salam sukses.

\section{Daftar Pustaka}

Jefkins, Frank. (2004). Public Relations. Jakarta: Erlangga.

Basrowi \& Suwandi. (2008). Memahami Penelitian Kualitatif. Jakarta: Rineka Cipta

Nugroho D, Riant. (2004). Komunikasi Pemerintahan. Jakarta: PT. Elex Media Komputindo.

Tubbs dan Moss. (2005). Human Communication. Singapore: Mc. Graw-Hill Inc. Daymon dan Holloway. (2002). Metode Riset Kualitatif dalam Public Relation \& Marketing Communications. Yogyakarta: Penerbit Bentang Anggota IKAPI.

Wolf, Martin. (2004). Why Globalization Works. Jakarta: Yayasan Obor Indonesia

Bungin, Burhan. (2007). Penelitian Kualitatif: Komunikasi, Ekonomi, Kebijakan Publik dan Ilmu Sosial lainnya. Jakarta: Putra Grafika.

Littlejohn, Stephen W \& Karen A. Foss. (2009). Teori Komunikasi, edisi 9. Jakarta: Salemba Humanika

Liliweri, Alo . (2011). Komunikasi serba ada serba makna. Jakarta: Kencana

McQuail, Denis. (2012). Teori Komunikasi Massa. Jakarta: Salemba Humanika.

Nasrullah, Rulli. (2015). Media Sosial: Perspektif Komunikasi, Budaya, dan Sosioteknologi. Bandung: Simbiosa Rekatama Media.

Abdullah dan Oktarina. (2017). Komunikasi dalam Perspektif Teori dan Praktik. Yogyakarta: CV Budi Utama.

Gunawan, Imam. (2014). Metode Penelitian Kualitatif Teori dan Praktik. Jakarta: PT. Bumi Aksara.

Azeharie, S. (2016). Fungsi Komunikasi Media Sosial Twitter Pelaksana Tugas Gubernur Dki Jakarta Basuki Tjahaja Purnama. Jurnal Komunikasi, 6(3), 8592.

Retrieved

from https://journal.untar.ac.id/index.php/komunikasi/article/view/42 